\title{
Formation of the $\mathrm{Ca}^{2+}$-activated photoprotein obelin from apo-obelin and mRNA inside human neutrophils
}

\author{
Anthony K. CAMPBELL,${ }^{*}$ Ashvin K. PATEL,${ }^{*}$ Zia S. RAZAVI $\dagger$ and Frank McCAPRA $\dagger$ \\ *Department of Medical Biochemistry, University of Wales College of Medicine, Heath Park, Cardiff CF4 4XN, U.K., \\ and $†$ School of Molecular Science, University of Sussex, Brighton BN1 9QJ, Sussex, U.K.
}

1. A method has been developed to incorporate the apoprotein of the $\mathrm{Ca}^{2+}$-activated photoprotein obelin, and mRNA purified from the hydroid Obelia, into the cytoplasm of intact human neutrophils. This was based on internal release from $\mathrm{pH}$-sensitive immunoliposomes taken up initially by phagocytosis. 2. Addition of the prosthetic group of obelin, coelenterazine, to these cells containing apo-obelin or Obelia mRNA resulted in formation of active $\mathrm{Ca}^{2+}$-activated obelin. 3. The obelin formed within the neutrophils responded to the chemotactic peptide $N$-formylmethionyl-leucyl-phenylalanine $(1 \mu \mathrm{M})$ and to the membrane attack complex of complement $\left(\mathrm{C} 5 \mathrm{~B} 6789_{\mathrm{n}}\right)$. 4. The formation of the apo-obelin from mRNA within neutrophils was inhibited by over $80 \%$ in the absence of added amino acids, and by over $90 \%$ by the protein-synthesis inhibitor puromycin $(100 \mu \mathrm{g} / \mathrm{ml})$. 5. The translation of Obelia mRNA inside cells provides a method for circumventing consumption of $\mathrm{Ca}^{2+}$-activated photoproteins during cell activation or injury, and for monitoring protein synthesis in living cells.

\section{INTRODUCTION}

Measurement of intracellular free $\mathrm{Ca}^{2+}$ is essential in the investigation of the molecular basis of cell activation and cell injury (Campbell, 1983, 1987, 1988a,b; Scarpa, 1985). In order to examine the role of $\mathrm{Ca}^{2+}$ in long-term regulatory phenomena such as cell development and differentiation, and to elucidate the chemisymbiotic interactions between intracellular signals necessary to provoke chemical thresholds in cells responding to stimuli or pathogens (Patel \& Campbell, 1987; Patel et al., 1987), it is necessary to measure cytosolic free $\mathrm{Ca}^{2+}$ in large numbers of individual cells. In spite of the ingenious and important invention of highly specific and sensitive fluorescent indicators for free $\mathrm{Ca}^{2+}$, such as fura 2 and indo 1 (Grynkiewicz et al., 1985), $\mathrm{Ca}^{2+}$-activated photoproteins such as aequorin and obelin still have valuable properties for measurement of intracellular free $\mathrm{Ca}^{2+}$ (Ashley \& Campbell, 1979; Blinks et al., 1978, 1982; Campbell et al., 1985). In particular, aequorin and obelin measure free $\mathrm{Ca}^{2+}$ over the range $10 \mathrm{nM}-100 \mu \mathrm{M}$, considerably wider than that with the fluors (Cobbold \& Rink, 1987), can be used readily at concentrations which do not disturb the $\mathrm{Ca}^{2+}$ balance of the cell, and are less susceptible to internal compartmentation or release from cells, which can seriously effect interpretation of fluorescent signals from developing or injured cells.

Micro-injection of limited numbers of single cells with aequorin has been achieved (Allen \& Blinks, 1978; Cobbold et al., 1983). However, there are two major problems encountered when using $\mathrm{Ca}^{2+}$-activated photoproteins to examine threshold phenomena (Campbell, 1983, 1987) in populations of small cells. Firstly, consumption of the photoprotein chromophore responsible for light production is rapid if the free $\mathrm{Ca}^{2+}$ remains greater than $1 \mu \mathrm{M}$ for more than a few minutes.
Thus, for example, in studying recovery of cells from attack by membrane pore formers, the free $\mathrm{Ca}^{2+}$ cannot be measured in recovered cells, because no detectable photoprotein remains (Morgan et al., 1986). Secondly, in order to correlate threshold end responses in cells with free $\mathrm{Ca}^{2+}$, it is necessary to examine hundreds or thousands of individual cells in one experiment, far more than can be achieved by using manual micro-injection.

The aim of the experiments described here was to incorporate the apoprotein of obelin, and its mRNA, into living cells and then re-form $\mathrm{Ca}^{2+}$-activatable photoprotein within the cell by addition of synthetic prosthetic group coelenterazine (Fig. 1; Shimomura \& Johnson, 1975; Campbell et al., 1981). Neutrophils, coupled with a new liposome method (Connor \& Huang, 1985), were chosen as a cell system epitomizing the problems of understanding the relationships between intracellular signals and end response in activated or injured cells (Patel \& Campbell, 1987; Patel et al., 1987).

\section{EXPERIMENTAL}

\section{Chemicals}

The chemotactic peptide f Met-Leu-Phe, puromycin, 2chloroadenosine, palmitic acid, $N$-hydroxysuccinimide, $N N^{\prime}$-dicyclohexylcarbodi-imide, L-homocysteine thiolactone hydrochloride, sodium deoxycholate, rat liver RNA, antifoam A and EGTA were purchased from Sigma (London) Chemical Co., Poole, Dorset, U.K. RPMI1640 tissue-culture medium was purchased from Flow Laboratories, Irvine, Ayrshire, Scotland, U.K. Dioleoyl phosphatidylethanolamine was purchased from Lipid Products, Nutfield, Surrey, U.K. Ethyl acetate (Sequanal grade) was purchased from Pierce (U.K.) Ltd., Cambridge, U.K. Rabbit reticulocyte lysate (N90) was 
obtained from Amersham International, Amersham, Bucks., U.K. Monoclonal antibody to human neutrophils (Tg1) was kindly given by Dr. P. C. Beverley, Imperial Cancer Research Fund, University College Hospital, London, U.K. Chemicals for coelenterazine synthesis were from Aldrich Chemical Co., Dorset, U.K. All other chemicals were AnalaR grade, from BDH Chemicals, Poole, Dorset, U.K.

\section{Obelia}

The hydroid Obelia geniculata was collected growing on fronds of the brown seaweed Laminaria or Sacchoriza by subaqua diver in Plymouth Sound as previously described (Campbell, 1974). Laminaria never exposed at low water was most thickly carpeted with Obelia between June and September. The seaweed was taken to the Marine Biological Association Laboratory and stored in a running seawater tank. Optimal yields of obelin were obtained by using seaweed stored for just a few hours. However, the hydroids were still visibly luminous after several days.

\section{Coelenterazine}

Coelenterazine \{3,7-dihydro-2-( $p$-hydroxybenzyl)-6(p-hydroxyphenyl)-8-benzylimidazo[1,2-a]pyrazine-3one \} was synthesized by the method of Inoue $e t$ al. (1975). p-Acetoxyphenylacetyl chloride required for the synthesis is best prepared using oxalyl chloride, since the use of other chlorinating reagents resulted in it being difficult to separate impurities which interfered with later steps. The $p$-nitroso- $N N$-dimethylaniline must be present as the hydrochloride to prevent side reactions (alkylation), and the p-acetoxybenzyl bromomethyl ketone must be used as soon as it is prepared. Purification of coelenterazine is best achieved by chromatography on an LH20 column (Pharmacia), eluted with aq. $80 \%$ (v/v) methanol to which $0.1 \%$ conc. $\mathrm{HCl}$ had been added. A $75 \mathrm{~cm} \times 3 \mathrm{~cm}$ column was used for the purification of $100 \mathrm{mg}$ of crude coelenterazine (yield $44 \mathrm{mg}$ ). Coelenterazine is the prosthetic group of coelenterate and radiolarian photoproteins, such as obelin and aequorin, and also acts as a conventional luciferin in certain luminous mysids, decapod shrimps, copepods, squid and fish (Shimomura, 1985; Campbell \& Herring, 1988). It was stored in the dark; samples were dried under argon with dessicant, at $-20^{\circ} \mathrm{C}$ or $-70^{\circ} \mathrm{C}$, where it was stable, and redissolved in methanol immediately before use. In aqueous or methanolic solution, coelenterazine is very unstable and highly light-sensitive. On a bright day more than $50 \%$ can be lost within 1-2 h. Even at $-20^{\circ} \mathrm{C}$ more than $50 \%$ can be oxidized within $24 \mathrm{~h}$. Solutions of coelenterazine were thus always stored in the dark. Coelenterazine was estimated at one of its absorption maxima $\left(\epsilon_{434}=8900 \mathrm{M}^{-1} \cdot \mathrm{cm}^{-1}\right.$; Hori et al., 1977). Oxidation results in loss of this absorbance maximum, the resulting compound, coelenteramide, being blue-fluorescent instead of the yellow-fluorescent coelenterazine. The two compounds could be separated readily on silica t.l.c. with ethyl acetate/methanol $(5: 1, \mathrm{v} / \mathrm{v})$ as solvent; $\boldsymbol{R}_{F}$ for coelenterazine 0.84 , for coelenteramide 0.61 .

\section{Assay of obelin}

A few microlitres of obelin were added to $0.5 \mathrm{ml}$ of $200 \mathrm{~mm}$-Tris/0.5 mM-EDTA, pH 7, and $0.5 \mathrm{ml}$ of $25 \mathrm{~mm}$ $\mathrm{CaCl}_{2}$ was added while the mixture was in front of a highly sensitive photomultiplier connected to a homebuilt computerized chemiluminometer (Campbell et al., 1985). Obelin was quantified as luminescent counts in the first $10 \mathrm{~s}\left(t_{1}=0.18 \mathrm{~s}, k=4 \mathrm{~s}^{-1} ; 1\right.$ count is equivalent to approx. 5 tipomol, i.e. $5 \times 10^{-21} \mathrm{~mol}$ ).

\section{Preparation of apo-obelin}

Apo-obelin was prepared from obelin after stimulation of luminescence by $\mathrm{Ca}^{2+}$ and removal of the coelenteramide formed by gel filtration (Shimomura \& Johnson, 1975; Shimomura \& Shimomura, 1981; Campbell et al., 1981). A more rapid and efficient method for purifying obelin than that reported previously (Campbell et al., 1979) was developed. Obelia was scraped off the seaweed, blotted, and homogenized $(2: 1, \mathrm{w} / \mathrm{v})$ in $100 \mathrm{~mm}$-Tris/ $50 \mathrm{~mm}-\mathrm{EDTA} / 0.5 \mathrm{M}-\mathrm{NaCl}, \mathrm{pH} 7$. After removal of particulate material by filtration first through nylon mesh and then a GFC+Whatman no. 1 filter paper, the filtrate was centrifuged at $35000 \mathrm{~g}$ for $30 \mathrm{~min}$. The pink supernatant was diluted with water 1:10 and passed through DEAE-cellulose in a Buchner funnel. The DEAE-cellulose was washed with $100 \mathrm{ml}$ of $10 \mathrm{~mm}$-Tris/ $5 \mathrm{mM}$-EDTA/ $50 \mathrm{~mm}-\mathrm{NaCl}, \mathrm{pH} \mathrm{7}$, then with $100 \mathrm{ml}$ of the same medium $+100 \mathrm{mM}-\mathrm{NaCl}$, and the obelin was eluted with the same medium $+500 \mathrm{~mm}-\mathrm{NaCl}$. The obelin could be stored frozen at $-70^{\circ} \mathrm{C}$, stable for several weeks. Obelin was purified further by $\left(\mathrm{NH}_{4}\right)_{2} \mathrm{SO}_{4}$ fractionation (50\%-satd. cut), removing the pink protein. Obelin could be further purified by elution from QAE (quaternary aminoethyl)-Sepharose and Sephadex G-100 as described for aequorin (Blinks et al., 1978). The final preparation was desalted against Chelex-treated water (Campbell \& Dormer, 1975) and concentrated by ultrafiltration in the presence of gelatin (final concn. $0.1 \%, \mathrm{w} / \mathrm{v}$ ) as protein carrier, freeze-dried, and stored at $-70^{\circ} \mathrm{C}$. Obelin was reconstituted in distilled water.

A few microlitres of stock obelin $\left(10^{6}-10^{9}\right.$ luminescent counts, equivalent to $5 \mathrm{fmol}-5 \mathrm{pmol}$, assuming an apparatus efficiency of $0.2 \%$ ) were added to $100 \mu \mathrm{l}$ of $105 \mathrm{~mm}$-Tris/0.75 mM-EDTA/500 mM- NaCl/5 mMmercaptoethanol/0.1\% (w/v) gelatin, pH 7. $\mathrm{CaCl}_{2}$ ( $2 \mathrm{mM}$ ) was added, producing a bright blue flash, and the obelin was consumed for 10-15 min at room temperature. EDTA (10 mM) was then added, and the apo-obelin was separated from reacted prosthetic group, now coelenteramide, on a $0.7 \mathrm{~cm} \times 8 \mathrm{~cm}$ Sephadex G-25 (superfine) column. This last step was, however, not necessary to demonstrate re-activation of apo-obelin to obelin. Apo-obelin was used either fresh or freeze-dried, since some preparations lost more than $50 \%$ activity when stored frozen overnight at $-20^{\circ} \mathrm{C}$.

Re-activation of apo-obelin to obelin (Fig. 1) was carried out by adding coelenterazine $(1-5 \mu 1$ of $100 \mu \mathrm{M})$ to $100 \mu$ l of apo-obelin in $10 \mathrm{~mm}$-Tris $/ 0.5 \mathrm{M}-\mathrm{NaCl} / 1 \mathrm{mM}$ EDTA/5 mM-mercaptoethanol/0.1\% gelatin, pH 7.4, and obelin formation was assayed up to $24 \mathrm{~h}$.

\section{Isolation of mRNA from Obelia}

RNA was extracted by grinding in a mortar and pestle $30-90 \mathrm{~g}$ of blotted Obelia hydroids ( 1 hydroid $=0.8 \mathrm{mg}$ ) in $4 \mathrm{M}$-guanidinium thiocyanate solution (approx. 1:1, $\mathrm{w} / \mathrm{v})$ containing sodium lauryl sarcosine $(5 \mathrm{~g} / \mathrm{l}), 25 \mathrm{~mm}-$ sodium citrate, $\mathrm{pH}$ 7, $0.1 \mathrm{M}$-mercaptoethanol and $0.1 \%$ antifoam A. Particulate material was removed by filtering through $300 \mu \mathrm{m}$ nylon mesh. The filtrate was centrifuged for $1 \mathrm{~min}$ at $10^{4} \mathrm{~g}$ in an Eppendorf microfuge, and the 
supernatant was layered in three tubes on to $4 \mathrm{ml}$ of $5.7 \mathrm{M}$ $\mathrm{CsCl} / 25 \mathrm{~mm}$-sodium citrate, $\mathrm{pH} 5$ (previously autoclaved with $0.2 \%$ diethyl pyrocarbonate), and centrifuged for $18 \mathrm{~h}$ at $10^{5} \mathrm{~g}$ in an MSE SS50 centrifuge. The RNA pellets were dissolved in $1 \mathrm{ml}$ of $10 \mathrm{~mm}$-Tris/1 mM-EDTA, pH 7.4, and extracted with neutralized phenol/Sevag [1:1 (v/v) water-saturated phenol/Sevag; Sevag = $\mathrm{CHCl}_{3}$ /pentan-2-ol (secondary amyl alcohol (24:1, $\mathrm{v} / \mathrm{v})]$. RNA, in the upper aqueous phase, was precipitated with $0.4 \mathrm{M}-\mathrm{NaCl}$ and $70 \%(\mathrm{v} / \mathrm{v})$ ethanol (final concn.) and stored at $-70{ }^{\circ} \mathrm{C}$. When required, the RNA was centrifuged $\left(10^{4} \mathrm{~g}\right.$ for $\left.30 \mathrm{~s}\right)$ and redissolved in $10 \mathrm{~mm}$ Tris/1 mM-EDTA, pH 7.4. The yield of RNA was approx. $0.16 \mathrm{mg} / \mathrm{g}$ wet wt. of hydroids or $0.17 \mu \mathrm{g} /$ hydroid, estimated from the $A_{260}$ by using calf liver RNA as standard $\left(A_{260} / A_{280}\right.$ for Obelia RNA $=1.95$, and for calf liver RNA $=1.52$ ).

mRNA was purified from total RNA by binding polyadenylated RNA to a $2 \mathrm{~cm} \times 0.7 \mathrm{~cm}$ column of oligo(dT)-cellulose equilibrated in $10 \mathrm{~mm}$-Tris ( $\mathrm{pH} \mathrm{7.4)/}$ $1 \mathrm{mM}-\mathrm{EDTA} / 0.4 \mathrm{M}-\mathrm{NaCl} / 0.5 \%$ (w/v) SDS and eluted with $10 \mathrm{~mm}$-Tris (pH 7.4)/1 mm-EDTA/0.5\% SDS. The yield for mRNA was approx. $2 \%$ of total RNA, estimated from the $A_{260}$. The purified mRNA was stored at $-70{ }^{\circ} \mathrm{C}$ as a precipitate in $10 \mathrm{~mm}$-Tris/1 mM-EDTA (pH 7.4) $/ 0.4 \mathrm{M}-\mathrm{NaCl} / 70 \%$ ethanol.

\section{Translation of Obelia RNA in vitro}

RNA $(2 \mu \mathrm{l})$ redissolved in $10 \mathrm{~mm}$-Tris/1 mM-EDTA, pH 7.4, was added to $10 \mu \mathrm{l}$ of rabbit reticulocyte lysate and incubated at $30^{\circ} \mathrm{C}$ for up to $1 \mathrm{~h}$. Then $50 \mu \mathrm{l}$ of 10 mM-Tris / 1 mM-EDTA / 5 mM-mercaptoethanol/0.1 \% gelatin, $\mathrm{pH} 7.4$, plus $1 \mu \mathrm{l}$ of $100 \mu \mathrm{M}$-coelenterazine in methanol were added, and obelin formation was assayed up to $24 \mathrm{~h}$.

\section{Isolation of human neutrophils}

Neutrophils were isolated from heparinized human blood as previously described (Patel et al., 1987). The yield was $3.5 \times 10^{7}-4 \times 10^{7}$ neutrophils over $40 \mathrm{ml}$ of blood, of which more than $99 \%$ were shown to be neutrophils by phase-contrast microscopy, and $98 \%$ viable by Trypan Blue exclusion.

\section{Liposome-neutrophil fusion}

Apo-obelin or RNA was entrapped within $\mathrm{pH}$ sensitive immunoliposomes by a modification of the method of Huang et al. (1983) and Connor \& Huang (1985). The method depends on uptake of $\mathrm{pH}$-sensitive immunoliposomes containing apo-obelin or mRNA by phagocytosis and then release of entrapped material into the cytoplasm as a result of fusion with the inner surface of the phagolysosome because of the low $\mathrm{pH}$. Liposomes were prepared by sonication of dioleoyl phosphatidylethanolamine with palmitoylhomocysteine (molar ratio 4:1) in $10 \mathrm{~mm}$-Tes containing apo-obelin or RNA. The liposomes were then coated with anti-neutrophil antibody $(\mathrm{Tg} 1)$ by addition of palmitoyl-Tg1. These immunoliposomes were incubated for $1 \mathrm{~h}$ at $4{ }^{\circ} \mathrm{C}$ with neutrophils $\left(3 \times 10^{7}-4 \times 10^{7}\right.$ cells $)$ in $\mathrm{Krebs} / \mathrm{Hepes}$ medium (no $\mathrm{Ca}^{2+}$ ), pH 7.4 (Patel et al., 1987), containing $0.5 \mathrm{~mm}$-EGTA and $16 \mathrm{~mm}$-glucose. Unbound liposomes were removed by centrifugation $\left(10^{4} \mathrm{~g}\right.$ for $\left.1 \mathrm{~min}\right)$ and cytoplasmic release of entrapped material induced by incubation for $1 \mathrm{~h}$ at $37^{\circ} \mathrm{C}$. The neutrophils were then allowed to recover for $1 \mathrm{~h}$ in Krebs/Hepes, $\mathrm{pH} 7.4$,
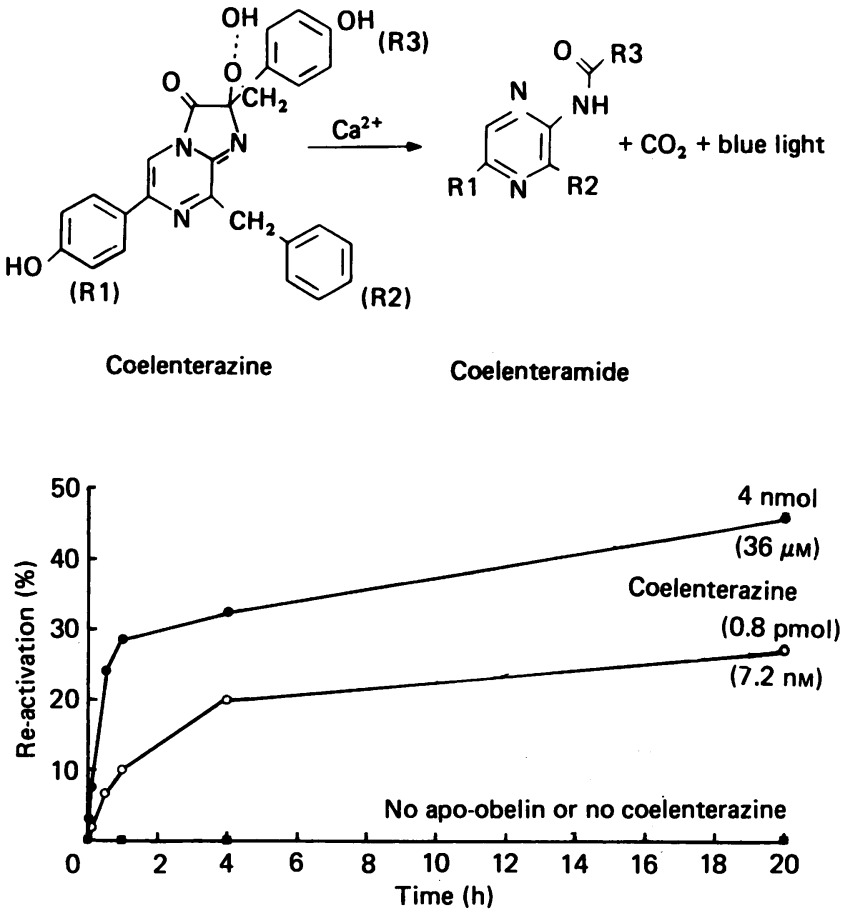

Fig. 1. Re-activation of apo-obelin to obelin in vitro

Apo-obelin ( $73 \mathrm{fmol}$ estimated) was prepared as described in the experimental section in $10 \mathrm{~mm}$-Tris $/ 0.5 \mathrm{M}$ $\mathrm{NaCl} / 1 \mathrm{~mm}$-EDTA/5 mM-mercaptoethanol/0.1\% gelatin. Coelenterazine $(O, 4 \mathrm{nmol} ; 36 \mu \mathrm{M} ; \bigcirc, 0.8 \mathrm{pmol}, 7.2 \mathrm{~nm})$ was then added and $\mathrm{Ca}^{2+}$-activatable obelin measured at the times indicated. Controls represent apo-obelin with no coelenterazine ( $\square$ ) but with $1 \mu \mathrm{l}$ of methanol per $100 \mu \mathrm{l}$, and coelenterazine with no apo-obelin ( $\square$ ). Results are expressed as percentages relative to original obelin used to prepare the apoprotein, and are means of two estimations.

containing $1.3 \mathrm{mM}-\mathrm{Ca}^{2+}$ and $0.1 \%(\mathrm{w} / \mathrm{v})$ bovine serum albumin. An alternative method was to induce fusion of immunoliposomes with the plasma membrane by preparing temperature-sensitive, as opposed to $\mathrm{pH}$ sensitive, liposomes (Huang et al., 1983; Connor \& Huang, 1985). There was no significant impairment of reactive-oxygen-metabolite production in the fused cells, as detected by luminol-dependent chemiluminescence.

Obelin was regenerated within neutrophils by addition of coelenterazine ( $2 \mu \mathrm{M}$ final concn.) to the extracellular medium and incubated for $30-60 \mathrm{~min}$ at room temperature $\left(20^{\circ} \mathrm{C}\right)$. Obelin formation was detected by chemiluminescence stimulated on addition of Nonidet P40 (final concn. $1 \%, w / v)$ to expose all obelin to $\mathrm{Ca}^{2+}$. Coelenterazine alone generated a small chemiluminescence in the presence of lysed cells. This could be decreased by washing the cells, before lysis with the Nonidet P40.

\section{RESULTS}

\section{Re-activation of obelin from apo-obelin}

Addition of coelenterazine to apo-obelin resulted in the formation of $\mathrm{Ca}^{2+}$-activatable obelin, detectable within a few seconds after the addition of the coelenterazine and complete within 6-12 h (Fig. 1). No further obelin formation was detectable after $24 \mathrm{~h}$, nor on 


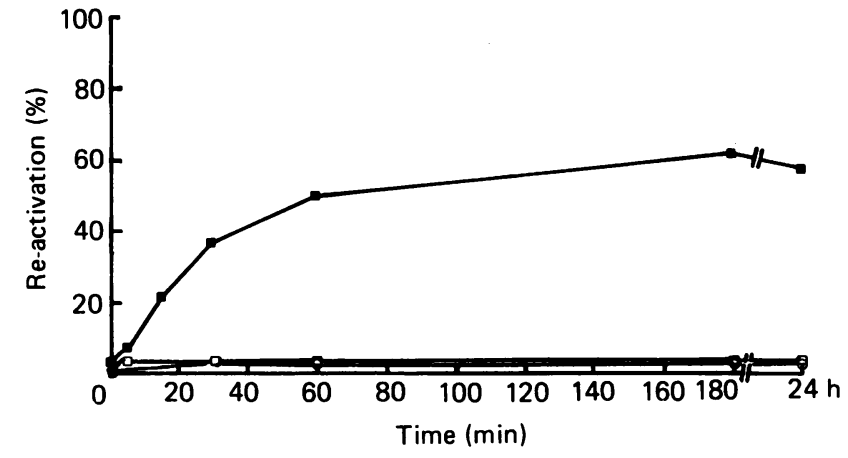

Fig. 2. Re-activation of apo-obelin inside neutrophils

Immunoliposomes containing apo-obelin were prepared and taken up by human neutrophils as described in the Experimental section. Coelenterazine $(2 \mu \mathrm{M})$ was added $(\square)$ and the cells were incubated at room temperature for up to $24 \mathrm{~h}$. $\mathrm{Ca}^{2+}$-activated obelin formed was measured by lysis of the cells with Nonidet P40 (final concn. 1\%, v/v) at various times. Control cells without apo-obelin but plus coelenterazine $(O)$ or cells with apo-obelin but without coelenterazine ( $\square$ ) were also monitored. Results represent the percentage of apo-obelin re-activated and are means of two estimations; $100 \%$ apo-obelin was estimated by lysing (freeze-thawing six times) cells loaded with apo-obelin, and re-activating the resulting lysate with coelenterazine (mean of three determinations).

addition of more coelenterazine at this time. However the recovery of re-formed obelin compared with the original, before isolation of the apo-obelin, varied from some $1 \%$ to $80-90 \%$, depending on conditions (Fig. 1). The $\mathrm{pH}$ optimum for apo-obelin formation and reactivation was broad, 7-8, but three other parameters were critical if maximum re-activation was to be obtained. The presence of high salt $(0.5 \mathrm{M}-\mathrm{NaCl})$, and protein carrier (albumin or gelatin) during the first $\mathrm{Ca}^{2+}$ stimulated consumption of obelin, to form apo-obelin, were essential. The presence of mercaptoethanol stabilizes apo-obelin, and, together with gelatin, it is necessary for maximum re-activation. However, significant re-activation was detectable in the absence of mercaptoethanol. Apo-obelin, like aequorin (Shimomura \& Shimomura, 1981; Inouye et al., 1986), has a $\mathrm{Ca}^{2+}$ activated oxygenase activity, resulting in a prolonged chemiluminescence in the presence of apo-obelin, $\mathrm{Ca}^{2+}$ and coelenterazine. However several other proteins, including albumin and human serum, have a coelenterazine oxygenase chemiluminescence. Gelatin resulted in a lower background chemiluminescence in the presence of coelenterazine alone, and was thus chosen as the protein carrier.

Apo-obelin appeared to have a relatively high affinity for coelenterazine. Although it has not been possible to produce a linear Lineweaver-Burk plot from either the initial rate of obelin re-formation or final yield, it appeared that the $K_{\mathrm{m}}$ for coelenterazine was at least as low as $0.1 \mu \mathrm{M}$, since no further increase in obelin formation was seen at concentrations of coelenterazine greater than 1-10 $\mu \mathrm{M}$. Apo-obelin was unstable, even when frozen with mercaptoethanol, although it could be stored freeze-dried.

\section{Re-activation of apo-obelin to obelin inside neutrophils}

Addition of coelenterazine $(2 \mu \mathrm{M})$ to neutrophils loaded with apo-obelin, by immunoliposome fusion as described in the Experimental section, resulted in formation of $\mathrm{Ca}^{2+}$-activated obelin, exposable by detergent lysis of the cells (Fig. 2). Obelin formation was detectable within a few minutes, but re-activation, in contrast with that in solution, was complete within 1-2 h. Approx. 1-2\% (Fig. 2) apo-obelin re-activation was detectable in the absence of coelentrazine, which could not entirely be explained by unspent obelin remaining in the apo-obelin preparation. Incorporation of obelin into the cells by this method was some 5 times that with obelin, since a considerable fraction of the latter was consumed during uptake into the cells. Addition of coelenterazine $(2 \mu \mathrm{M})$ to cells without apoobelin resulted in a small chemiluminescence of some 100 c.p.s. per $10^{6}$ cells when detergent was added. The source of this 'oxygenase' activity is unknown, but may be related to the enhanced chemiluminescence of imidazolopyrazines in dimethyl formamide and micelles (Goto \& Fukatsu, 1969).

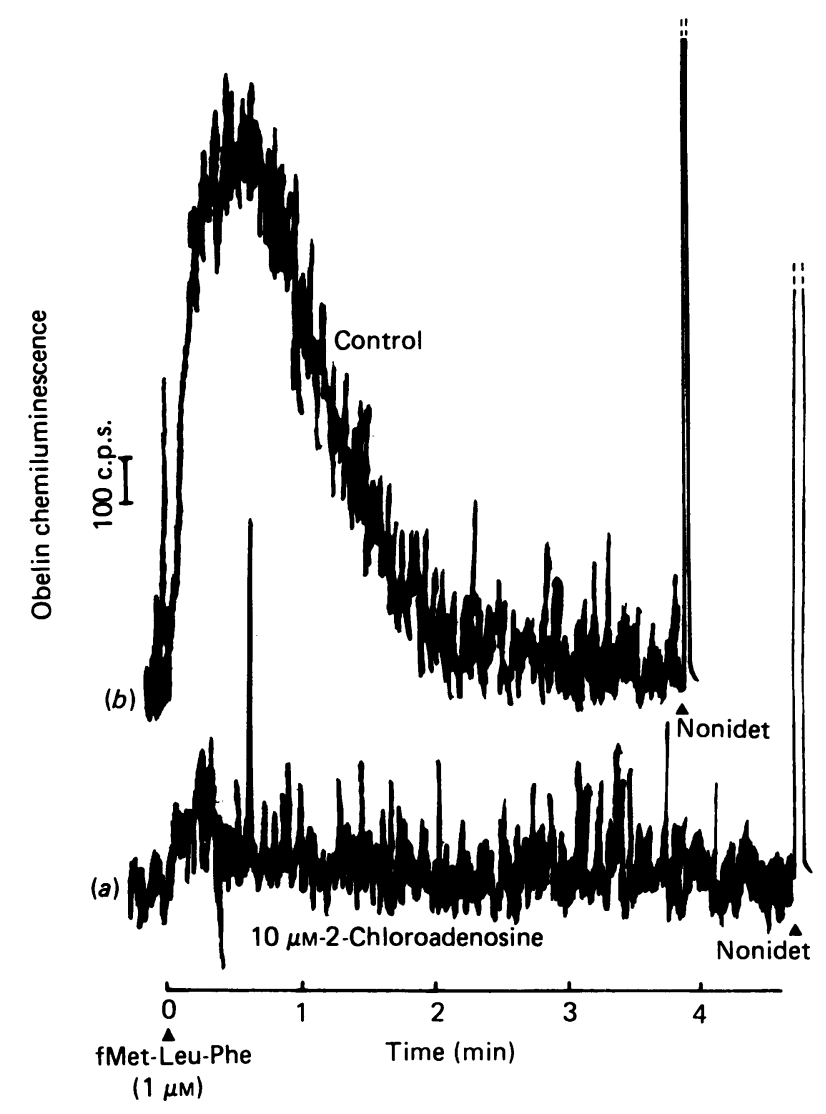

Fig. 3. Response of re-activated apo-obelin inside neutrophils

Apo-obelin was incorporated into human neutrophils as described in Fig. 2, and obelin was re-formed by addition of coelenterazine $(2 \mu \mathrm{M})$ for $1 \mathrm{~h}$ at room temperature. These cells $\left(10^{7} / \mathrm{ml}\right)$ were washed in Krebs $/$ Hepes $/ 0.1 \%$ bovine serum albumin, $\mathrm{pH} 7.4$, and resuspended in the same medium. fMet-Leu-Phe $(1 \mu \mathrm{M})$ in the presence $(a)$ or the absence $(b)$ of 2-chloro adenosine $(10 \mu \mathrm{M})$ was added and the obelin chemiluminescence monitored. Results are two representative traces of obelin chemiluminescence against time. 


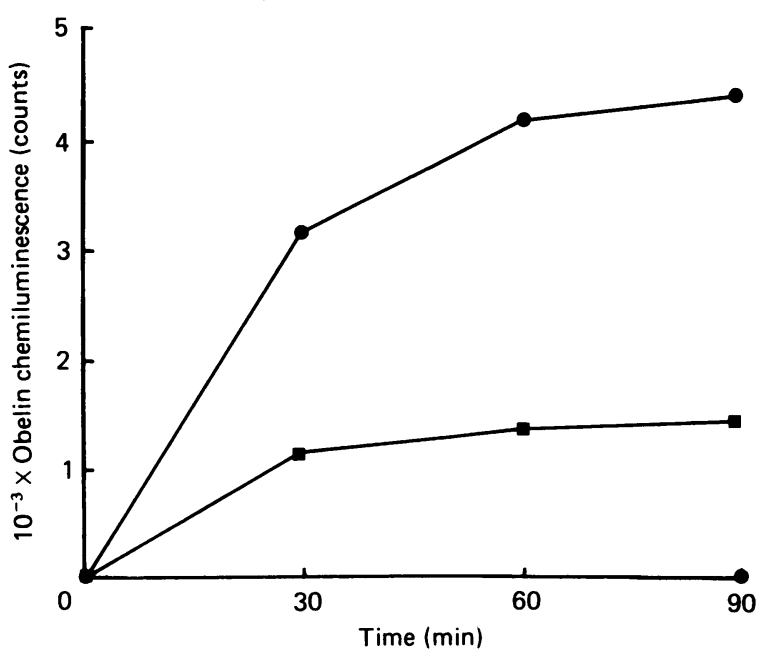

Fig. 4. Translation of Obelia mRNA in vitro

Crude RNA ( $\square$ ) or purified mRNA (O) (both $2 \mu \mathrm{l}$ ), or $2 \mu \mathrm{l}$ of $10 \mathrm{~mm}$-Tris/1 mM-EDTA, pH 7.4 (O) (see the Experimental section), from Obelia were incubated with $5 \mu \mathrm{l}$ of rabbit reticulocyte lysate $(O, \square, O)$ or $5 \mu \mathrm{l}$ of $10 \mu \mathrm{m}$-Tris/1 mM-EDTA, pH $7.4(\triangle)$, for $1 \mathrm{~h}$ at $30^{\circ} \mathrm{C}$. Then $50 \mu \mathrm{l}$ of $10 \mathrm{~mm}-$ Tris/ $0.5 \mathrm{M}-\mathrm{NaCl} / 1 \mathrm{~mm}$-EDTA/ 5 mM-mercaptoethanol $/ 0.1 \%$ gelatin, $\mathrm{pH} 7$, was added, followed by $1 \mu \mathrm{l}$ of $100 \mu \mathrm{M}$-coelenterazine in methanol. Formation of $\mathrm{Ca}^{2+}$-activated obelin was measured up to $3 \mathrm{~h}$ and expressed as luminescence counts recorded in the $10 \mathrm{~s}$ after addition of $\mathrm{Ca}^{2+}(25 \mathrm{~mm})$.

The re-activated obelin, from apo-obelin, appeared to be cytosolic, since a cell stimulus, fMet-Leu-Phe $(1 \mu \mathrm{M})$, known to increase cytosolic free $\mathrm{Ca}^{2+}$ (Hallett \& Campbell, 1982; Campbell \& Hallett, 1983; Lew et al., 1985), produced a large increase in intracellular obelin chemiluminescence (Fig. 3). This cytosolic $\mathrm{Ca}^{2+}$ transient was inhibitable by more than $90 \%$ by the secondary regulator 2-chloroadenosine (10 $\mu \mathrm{M}$; Fig 3). 2-Chloroadenosine inhibits activation of reactive-oxygenmetabolite production in neutrophils, via cyclic AMP (Roberts et al., 1985). No detectable rise in cytosolic free $\mathrm{Ca}^{2+}$ is observed with phorbol myristate acetate $(10 \mathrm{ng} /$ $\mathrm{ml})$ or latex particles $\left(4 \times 10^{9}\right.$ beads $)$, since these activate neutrophils via a mechanism independent of a rise in cytosolic free $\mathrm{Ca}^{2+}$ (Hallett \& Campbell, 1983). Stimulation of intra-neutrophil obelin by fMet-Leu-Phe was not the result of secretion, since release of fluorescent albumin, originally entrapped with liposomes, from activated cells was undetectable $(<0.1 \%)$ relative to unstimulated cells.

\section{Formation of apo-obelin from mRNA}

Incubation of total RNA or mRNA, isolated from Obelia, with rabbit reticulocyte-lysate translation cocktail resulted in formation of apo-obelin, detectable within a few minutes and complete within $1-2 \mathrm{~h}$ at $30^{\circ} \mathrm{C}$ (Fig. 4). The higher specific activity of the purified $\mathrm{mRNA}$ resulted in greater apo-obelin activity. No apo-obelin or obelin was detectable in the absence of RNA or the rabbit reticulocyte lysate. Maximum formation of apo-obelin required maintaining as high a ratio of lysate/RNA (v/v) as possible.

Addition of coelenterazine $(2 \mu \mathrm{M})$ to neutrophils,

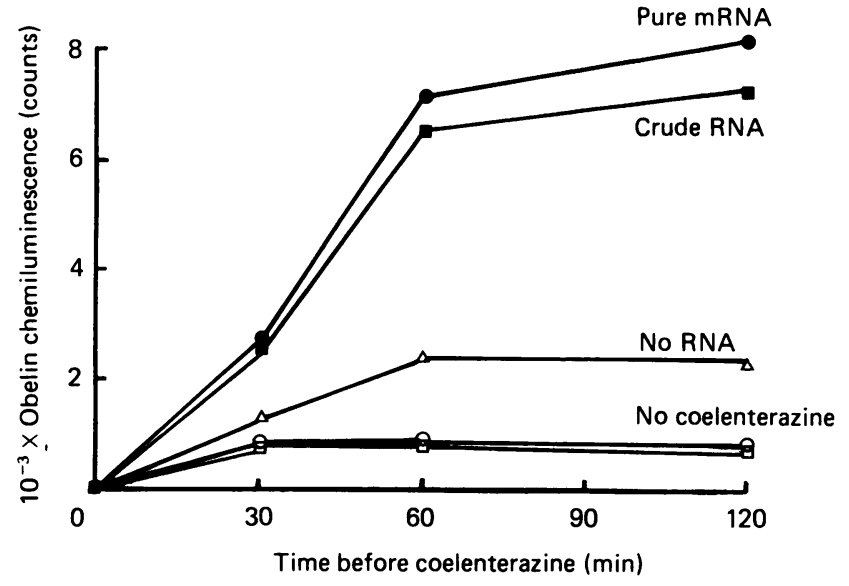

Fig. 5. Formation of obelin from mRNA inside neutrophils

Crude RNA $(\square, \square)$ and purified mRNA $(O, O)$ from Obelia was incorporated into human neutrophils by using immunoliposome uptake and internal fusion as described in the Experimental section; mRNA had $A_{260}=0.17$, equivalent to $2 \times 10^{6}$ luminescence counts of obelin in the translation assay in vitro. Cells were then incubated at $37^{\circ} \mathrm{C}$ in RPMI 1640 tissue-culture medium containing 21 amino acids including glutamine. The cells were washed at 30,60 or $120 \mathrm{~min}$ and resuspended in Krebs/Hepes, pH 7.4, containing $0.1 \%$ bovine serum albumin. Coelenterazine $(1 \mu \mathrm{M})$ was added $(\odot, \square, \triangle)$ and the cells were incubated at room temperature for $30 \mathrm{~min}$, washed and resuspended in Krebs/Hepes, pH 7.4. Nonidet P40 (final concn. $1 \%, v / v)$ was then added, with the cells in the chemiluminometer, to expose to $\mathrm{Ca}^{2+}$ any obelin formed. Results were expressed as obelin luminescence recorded $10 \mathrm{~s}$ after exposure to $\mathrm{Ca}^{2+}$. Controls were cells containing RNA without coelenterazine $(\square, O)$ or no RNA $(\triangle)$. The $\mathrm{Ca}^{2+}$-independent chemiluminescence of cells plus coelenterazine when Nonidet P40 was added was 130 240 c.p.s., and was subtracted from all the other results. Cells containing mRNA, but without coelenterazine, produced $45-50$ c.p.s.

which had entrapped RNA from immunoliposomes, resulted in formation of $\mathrm{Ca}^{2+}$-activated obelin up to $1 \mathrm{~h}$ (Fig. 5). This chemiluminescence was some 10-fold greater than the control cells without coelenterazine and some 4-fold greater than that when coelenterazine was incubated with cells not containing Obelia RNA. This chemical blank was also not inhibited by removal of $\mathrm{Ca}^{2+}$. That the formation of apo-obelin was the result of intracellular translation of mRNA was confirmed by the fact that it was inhibited by more than $80 \%$ in the absence of amino acids, and by more than $90 \%$ in the presence of puromycin $(100 \mu \mathrm{g} / \mathrm{ml})$, after subtraction of the coelenterazine blank (Fig. 6).

\section{DISCUSSION}

The results reported here show, for the first time, that a bioluminescent protein can be synthesized within mammalian cells from either its apoprotein or its mRNA (Figs. 2-6). The resulting photoprotein was capable of producing light when the cells responded to a natural stimulus, namely the chemotactic peptide fMetLeu-Phe (Fig. 3), known to require a rise in cytosolic free 


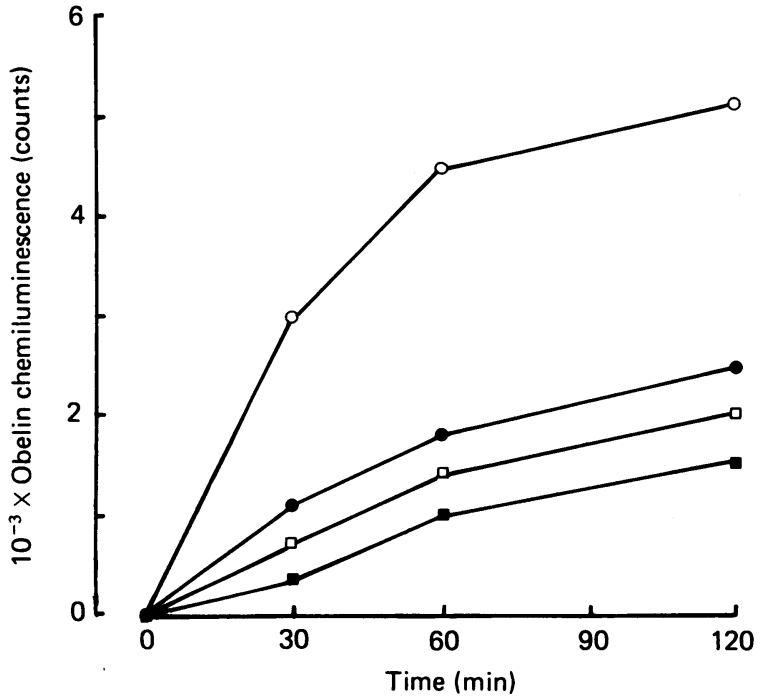

Fig. 6. Inhibition of translation of obelin mRNA in neutrophils

Purified mRNA was incorporated into human neutrophils as described in Fig. 5. Cells were then incubated in Krebs/ Hepes + $1.3 \mathrm{~mm}^{-\mathrm{Ca}^{2+}}$, pH 7.4 $(\square, \square)$, or RPMI $1640+21$ amino acids including glutamine $(O, O)$, in the absence $(\square, \bigcirc)$ or the presence $(\square, O)$ of puromycin $(200 \mu \mathrm{g} / \mathrm{ml})$ as an inhibitor of protein synthesis. The cells were washed at 30, 60 and $120 \mathrm{~min}$ and resuspended in Krebs/ Hepes $+1.3 \mathrm{~mm}-\mathrm{Ca}^{2+}$. Coelenterazine $(2 \mu \mathrm{M})$ was then added and obelin formation at room temperature assayed after 30 min by exposure to $\mathrm{Ca}^{2+}$ by lysis of the cells with Nonidet P40. Results are expressed as obelin luminescence against time of incubation before addition of coelenterazine, after correction for the $\mathrm{Ca}^{2+}$-independent chemiluminescence of cells plus coelenterazine (130240 c.p.s.).

$\mathrm{Ca}^{2+}$ to activate neutrophils fully (Hallett \& Campbell, 1982, 1984; Campbell \& Hallett, 1983; Lew et al., 1985).

Re-activation in solution of apo-aequorin (Shimomura \& Johnson, 1975; Shimomura \& Shimomura, 1981; Inouye et al., 1986), obelin and the radiolarian photoprotein thalassicollin (Campbell et al., 1981) have been reported previously. Also, apo-aequorin has been formed from cDNA in Escherichia coli (Inouye et al., 1986). However, in several reports re-activation of apoprotein isolated from native photoprotein triggered by $\mathrm{Ca}^{2+}$ the recovery has been considerably less than $50 \% . \mathrm{O}_{2}$ is required for re-activation from apoprotein and coelenterazine (Fig. 1), and both apo-aequorin and apo-obelin appear to contain a thiol group which has to be protected. The experiments reported here show that the conditions during the $\mathrm{Ca}^{2+}$-activated step are critical if maximum yield of reactivatable apo-obelin is to be achieved. In the absence of high salt and a protein carrier such as gelatin $(0.01-0.1 \%), \mathrm{Ca}^{2+}$ appeared to inactivate obelin irreversibly. Protein carrier has previously been necessary to prevent denaturation via a 'dark' reaction at $37^{\circ} \mathrm{C}$ (Campbell \& Dormer, 1975), and to protect obelin during freeze-drying (Campbell, 1974).

A further interesting new finding was the $\mathrm{Ca}^{2+}$. independent 'luciferase' activity of other proteins such as albumin, provoking coelenterazine chemi- luminescence. This activity was also found in human plasma, and may change in disease states such as myocardial infarction. Albumin is the major source of free thiol groups in blood plasma, where it acts as an oxygen-metabolite scavenger (Holt et al., 1984). Imidazolopyrazines chemiluminesce strongly in certain micelles, and in aprotic solvents such as dimethyl formamide and dimethyl sulphoxide (Goto \& Fukatsu, 1969), in the absence of protein. This hydrophobic requirement may point to the evolutionary origin of the active centre of coelenterazine photoproteins and luciferases. The former are found only in coelenterates and radiolarians, whereas the latter occur in anthozoans, some squid and fish, decapod shrimps and copepods (Campbell et al., 1981; Shimomura, 1985; Campbell \& Herring, 1988). Re-activation of apo-obelin to obelin provides a highly sensitive assay for coelenterazine, down to 10-100 amol, enabling this to be detected in individual organisms from these and other animal groups, both luminous and non-luminous (Campbell \& Herring, 1988; Shimomura, 1987).

The efficient translation, within live neutrophils, of Obelia mRNA to form apo-obelin, which can then be converted into obelin (Figs. 5 and 6), was perhaps surprising, in view of reports that neutrophils are poor at protein synthesis (Klebanoff \& Clark, 1978). The heterogeneity of protein synthesis within the cell population is at present unknown. However, the sensitivity of detection of obelin should ultimately enable rates of mRNA translation and turnover to be monitored in single living cells.

Bacterial clones producing apo-aequorin cDNA were originally identified by using an oligonucleotide probe (Inouye et al., 1985; Prasher et al., 1985). cDNA coding for apo-obelin has been produced and detected by its ability to form mRNA in the presence of RNA polymerase II and nucleotides. Thus clones producing cDNA for such bioluminescent proteins should now be detectable by light emission, provided that an appropriate expression vector is used.

In conclusion, the results in this paper provide the technology for establishing the chemisymbiotic relationship between intracellular signals, energy demand and the end response of single eukaryotic cells, essential if the molecular basis of chemical thresholds in cell activation and injury is to be defined (Campbell, $1988 a$ ). We have previously established the existence of such thresholds occurring at different times and at different concentrations of stimuli in individual neutrophils (Patel \& Campbell, 1987; Patel et al., 1987). Detection of apo-obelin will now enable us to monitor free $\mathrm{Ca}^{2+}$ inside single cells, and eventually organelles, as well as thresholds for protein synthesis and mRNA turnover. It also provides an exquisitely sensitive assay for coelenterazine to help discover the biosynthetic pathway and evolutionary origin of this unique compound.

We thank our colleague Dr. Noor Kalsheker for many helpful discussions and free access to his method sheets for RNA extraction, and M.E.T. Ryall for constructing our chemiluminometers. We thank the Director and staff of the Marine Biological Association Laboratory, Plymouth, for facilities and an inspiring environment. A.K.C. thanks the Medical Research Council and the Browne and Maurice Hill bequest fund of the Royal Society for financial support. 


\section{REFERENCES}

Allen, D. G. \& Blinks, J. R. (1978) Nature (London) 273, 509-513

Ashley, C. C. \& Campbell, A. K. (eds.) (1979) Detection and Measurement of Free $\mathrm{Ca}^{2+}$ in Cells, Elsevier/North-Holland, Amsterdam

Blinks, J. R., Mattingley, P. H., Jewell, B. R., van Leeuwan, M., Harrer, G. C. \& Allen, D. G. (1978) Methods Enzymol. 57, 292-328

Blinks, J. R., Wier, W. G., Hess, P. \& Prendergast, F. G. (1982) Prog. Biophys. Mol. Biol. 40, 1-114

Campbell, A. K. (1974) Biochem. J. 143, 411-418

Campbell, A. K. (1983) Intracellular Calcium: Its Universal Role as Regulator, John Wiley, Chichester

Campbell, A. K. (1987) Clin. Sci. 72, 1-10

Campbell, A. K. (1988a) Chemiluminescence: Principles and Biomedical Applications, Ellis Horwood/VCH, Chichester, in the press

Campbell, A. K. (1988b) in Calcium in Human Biology (Nordin, B. E. C., ed.), Springer Verlag, London, in the press

Campbell, A. K. \& Dormer, R. L. (1975) Biochem. J. 152, 255-265

Campbell, A. K. \& Hallett, M. B. (1983) J. Physiol. (London) 338, 537-562

Campbell, A. K. \& Herring, P. J. (1988) RRS Discovery Reports Cruise 168, Institute of Oceanographic Science, Wormley, Surrey

Campbell, A. K., Lea, T. J. \& Ashley, C. C. (1979) in Detection and Measurement of Free $\mathrm{Ca}^{2+}$ in Cells (Ashley, C. C. \& Campbell, A. K., eds.), pp. 13-72, Elsevier/North-Holland, Amsterdam

Campbell, A. K., Hallett, M. B., Daw, R. A., Ryall, M. E. T., Hart, R. C. \& Herring, P. J. (1981) in Bioluminescence and Chemiluminescence (DeLuca, M. \& McElroy, W. D., eds.), pp. 601-607, Academic Press, New York

Campbell, A. K., Hallett, M. B. \& Weeks, I. (1985) Methods Biochem. Anal. 31, 317-416

Cobbold, R. H. \& Rink, T. J. (1987) Biochem. J. 248, 313-328

Cobbold, P. H., Cuthbertson, K. S. R., Goyns, M. B. \& Rice, V. (1983) J. Cell Sci. 61, 123-136

Connor, J. \& Huang, L. (1985) J. Cell Biol. 101, 582-589
Goto, T. \& Fukatsu, H. (1969) Tetrahedron Lett. 49, 4299-4302

Grynkiewicz, G., Poinie, M. \& Tsien, R. Y. (1985) J. Biol. Chem. 260, 3440-3450

Hallett, M. B. \& Campbell, A. K. (1982) Nature (London) 295, 155-158

Hallett, M. B. \& Campbell, A. K. (1983) Biochem. J. 213, 459-465

Hallett, M. B. \& Campbell, A. K. (1984) Cell Calcium 5, 1-19

Holt, M. E., Ryall, M. E. T. \& Campbell, A. K. (1984) Br. J. Exp. Pathol. 65, 231-241

Hori, K., Charbonneau, H., Hart, R. C. \& Cormier, M. J. (1977) Proc. Natl. Acad. Sci. U.S.A. 74, 4285-4287

Huang, A., Kennel, S. J. \& Huang, L. (1983) J. Biol. Chem. 258, 14034-14040

Inoue, S., Sugiura, S., Kakoi, H., Hasizuno, K., Goto, T. \& Iio, H. (1975) Chem. Lett. 141-144.

Inouye, S., Noguchi, M., Sukaki, Y., Takagi, Y., Miyata, T., Iwanaga, S., Miyata, T. \& Tsuji, F. I. (1985) Proc. Natl. Acad. Sci. U.S.A. 82, 3154-3158

Inouye, S., Sakaki, Y., Goto, T. \& Tsuji, F. I. (1986) Biochemistry 25, 8425-8429

Klebanoff, S. J. \& Clark, R. A. (1978) The Neutrophil: Function and Clinical Disorders, p. 347, North-Holland, Amsterdam

Lew, D. C., Andersson, T., Hed, T., Di Virgilio, F., Pozzan, T. \& Stendahl, O. (1985) Nature (London) 315, 509-511

Morgan, B. P., Luzio, J. P. \& Campbell, A. K. (1986) Cell Calcium 7, 399-411

Patel, A. K. \& Campbell, A. K. (1987) Immunology 60, 135-146

Patel, A. K., Hallett, M. B. \& Campbell, A. K. (1987) Biochem. J. 248, 173-180

Prasher, D., McCann, R. O. \& Cormier, M. J. (1985) Biochem. Biophys. Res. Commun. 126, 1259-1268

Roberts, P. A., Newby, A. C., Hallett, M. B. \& Campbell, A. K. (1985) Biochem. J. 227, 669-674

Scarpa, A. (Ed.) (1985) Cell Calcium 6, 1/2

Shimomura, O. (1985) Symp. Soc. Exp. Biol. 38, 351-372

Shimomura, O. (1987) Comp. Biochem. Physiol. B 86, 361-365

Shimomura, O. \& Johnson, F. H. (1975) Nature (London) 256, 236-238

Shimomura, O. \& Shimomura, A. (1981) Biochem. J. 199, 825-828

Received 18 November 1987; accepted 25 January 1988 